\title{
POTENSI TANAMAN CERMAI DALAM MENGATASI ASMA
}

\author{
Anisa Zulfiya Rahmah, Jihan Nur Pratiwi \\ Fakultas Kedokteran, Universitas Lampung, Jl. Prof. Dr. Ir. Sumantri Brojonegoro No.1, Gedong \\ Meneng, Kec. Rajabasa, Kota Bandar Lampung, Lampung, Indonesia 35145 \\ *anisazulfiya23@gmail.com (+6285263702658)
}

\begin{abstract}
ABSTRAK
Asma adalah gangguan inflamasi kronik saluran napas memunculkan gejala episodik berulang berupa sesak napas, dada terasa berat, mengi dan muncul terutama malam dan atau siang. Pencetus serangan asma dapat disebabkan oleh sejumlah faktor seperti alergen, virus, bahan iritan yang menginduksi respon inflamasi. Cermai mengandung komponen anti-inflamasi aktif yang telah banyak digunakan oleh pengobatan tradisional sebagai upaya pengobatan asma. Tujuan dari tinjauan pustaka ini adalah untuk melaporkan temuan ilmiah terbaru tentang peran kandungan cermai dalam mengatasi asma dengan sifatnya sebagai antiinflamasi dan menurunkan kadar IgE. Metode yang digunakan dalam artikel berjenis tinjauan pusta ka ini adalah literature searching method melalui database NCBI dan Google Scholar. Tahun penerbitan sumber pustaka adalah dari tahun 1991 sampai tahun 2018 dengan 21 sumber pustaka dan 13 sumber yang dapat digunakan. Tema yang dikumpulkan terkait dengan kandungan cermai dalam mengatasi asma. Hasil dari sintesis artikel yang telah ditemukan yaitu cermai bermanfaat dalam mengurangi kejadian asma.
\end{abstract}

Kata kunci: anti-inflamasi, asma, phyllantus acidus

\section{THE POTENTION OF STAR GOOSEBERRY IN OVERCOMING ASTHMA}

\begin{abstract}
Asthma is a chronic inflammation of the airways causing recurrent episodic symptoms in the form of wheezing, shortness of breath, chest feels heavy and coughing especially at night and / or early morning. Triggers of asthma attacks can be caused by a number of factors such as allergens, viruses, irritants that induce an inflammatory response. Cermai contains active antiinflammatory components that have been widely used by traditional medicine as an effort to treat asthma. The purpose of this literature review is to report the latest scientific findings about the role of chewing content in overcoming asthma with its anti-inflammatory properties and lower IgE levels. The method of this literature review used is article search through the NCBI database and Google Scholar. The year of publication of library resources is from 1991 to 2018 with 21 library sources and 13 sources that used in this review. The themes collected are related to the content of the mirror in dealing with asthma. The results of the synthesis of articles that have been found are useful in reducing the incidence of asthma.
\end{abstract}

Keywords: anti-inflammation, asthma, phyllantus acidus

\section{PENDAHULUAN}

Asma adalah gangguan inflamasi kronik saluran napas yang melibatkan banyak sel dan elemennya. Inflamasi terus menerus menyebabkan hiperresponsif yang meningkat pada jalan napas sehingga timbul gejala episodik berulang berupa sesak napas, dada terasa berat, mengi, dan terutama malam dan atau siang hari (PDPI, 2004).

Prevalensi asma banyak dipengaruhi oleh banyak faktor antara lain jenis 
kelamin, umur, status atopi, keturunan, dan lingkungan. Pada masa kanakkanak ditemukan prevalensi anak lakilaki dibanding anak perempuan sebesar 1,$5 ; 1$ tetapi pada dewasa perbandingan laki-laki dan perempuan sama besar, dan ketika perempuan menopause perbandingannya lebih besar dari lakilaki. Di indonesia prevalensi asma berkisar antara 5-7\% (Sundaru, Heru, dan Sukamto, 2006).

Pencetus serangan asma dapat disebabkan oleh sejumlah faktor seperti alergen, virus, bahan iritan yang menyebabkan munculnya respon inflamasi. Respon ini dibagi menjadi reaksi asma dini dan reaksi asma lambat. Setelah kedua reaksi ini, proses berlanjut menjadi reaksi inflamasi kronik. Perpu Asma disebabkan oleh inflamasi dinding saluran nafas. Terdapat peningkatan berbagai sel inflamasi pada umumnya eosinofil, basofil, sel mast, makrofag, dan tipe limfosit tertentu dapat ditemukan pada biopsi dinding saluran napas dan cairan bilas bronkoalveolar pada pasien asma. (Goodman dan Gilman, 2012).

Faktor resiko asma dibagi menjadi genetik yaitu berupa hiperreaktivitas, atopi, jenis kelamin, ras/etnik, faktor yang memodifikasi penyakit genetik. Lalu faktor lingkungan yaitu perubahan cuaca, alergen di dalam maupun di luar ruangan, makanan, obat, emosi berlebih, polusi udara, asap rokok, dan lainnya (PDPI, 2004).

Tujuan utama dalam tatalaksana asma adalah mempertahankan kualitas hidup agar penderita asma dapat melakukan aktifitas sehari-hari tanpa hambatan yang berarti. Penatalaksanaan asma dibagi menjadi serangan asma akut dan jangka panjang. Pada serangan akut, obat yang digunakan yaitu bronkodilator beta-2 agonis cepat dan ipratropium bromida dan kortikosteroid. Sementara pada tatalaksana jangka panjang berprinsip pada edukasi, obat asma sebagai pengontrol, dan kebugaran penderita (Supari, 2008).

Cermai (Phyllantus acidus) umumnya dikenal sebagai harfarauri atau star gooseberry, adalah tanaman yang tersebar luas di India dan negara Asia lainnya. Tingginya sekitar 4-6 m dan daun tipis berseling (Christhope, 2006). Cermai telah digunakan dalam pengobatan tradisional untuk mengobati beberapa gangguan terkait nyeri, inflamasi dan stres oksidatif seperti rematik, bronkitis, asma, gangguan pernapasan, juga penting untuk meningkatkan kecerdasan dan meningkatkan daya ingat (Sahab et al., 2016).

Komponen anti-inflamasi aktif yang dikandung oleh cermai telah banyak digunakan oleh pengobatan tradisional sebagai upaya pengobatan asma. Untuk itu tujuan penelitian berupa tinjauan pustaka ini dilakukan sebagai upaya mengetahui mekanisme manfaat dari kandungan cermai terhadap asma.

\section{METODE}

Metode yang digunakan adalah literature searching method. Sumber pustaka yang digunakan dalam artikel ini melibatkan 21 pustaka baik yang berasal dari buku, jurnal nasional atau internasional, maupun website dan terdapat 13 daftar pustaka yang digunakan dalam mereview potensi cermai. Penelusuran sumber pustaka dalam artikel ini melalui database NCBI dan Google Scholar dengan kata kunci Phyllantus acidus, Antiinflammation, Asthma. Pemilihan artikel sumber pustaka dilakukan dengan melakukan peninjauan pada judul dan abstrak yaitu 
membahas tentang potensi buah cermai dalam mengatasi asma. Tahun penerbitan sumber pustaka dalam penulisan artikel ini adalah 1991 hingga tahun 2018.

\section{HASIL}

Cermai telah digunakan untuk pengobatan beberapa penyakit termasuk gangguan yang berhubungan dengan inflamasi seperti ruam kulit, kulit psoriasis, radang selaput lendir hidung dan gangguan pernapasan seperti asma. Buah cermai mengandung asam asorbat, flavonoid, adenosin dan kalsium yang dapat berperan sebagai anti inflamasi yang mencegah sekresi histamin dan menurunkan IgE sehingga bermanfaat untuk mengurangi kejadian asma.

Cermai mengandung flavonoid dapat menghambat influx $\mathrm{Ca} 2+$ yang berperan dalam mencegah terjadinya degranulasi dari sel mast. Dengan dihambatnya degranulasi sel mast maka sekresi amin vasoaktif, seperti histamin, mediator lipid serta sitokin yang berperan dalam proses inflamasi pada peristiwa alergi berkurang (Burgos et al, 2000).

Flavonoid juga meningkatkan sistem imun alami (didapat) dan sistem imun spesifik (adaptif) yang berperan sebagai antiinflamasi, antialergi, antidiabetes dan menghambat pertumbuhan tumor (Guntur, 2004).

Potensi anti-inflamasi ekstrak daun metanol cermai secara signifikan ( $p$ $<0,01)$ menghambat produksi oksida nitrat (NO) yang diperantarai LPS, menghambat produksi PGE2 yang diinduksi LPS. Ekstrak daun (300 $\mathrm{ug} / \mathrm{mL}$ ) secara signifikan menekan produksi sitokin pro-inflamasi yang diinduksi LPS termasuk interleukin (IL)-1 $\beta$, IL-6, dan tumor necrosis factor- $\alpha($ TNF- $\alpha)$. Produksi NO ditekan oleh quercetin $(2 \mu \mathrm{M})$ dan kaempferol $(10 \mu \mathrm{M})$ (Hossen et al., 2015).

Pemberian ekstrak daun ceremai dosis $10 \mathrm{mg} / \mathrm{mencit} /$ hari secara per-oral mampu menurunkan kadar Ig E, secara bermakna mendekati nilai normal. Kemampuan ekstrak daun ceremai dalam menurunkan kadar Ig E tidak berbeda secara bermakna dibandingkan antihistamin generasi III (Subijanto dan Diding, 2006).

\section{PEMBAHASAN}

Definisi asma menurut Global Initiative for Asthma (GINA) yaitu terdapat inflamasi kronik pada saluran napas disertai peran sel mast, eosinofil dan limfosit T. Pada individu yang rentan menunjukkan gejala episode mengi yang berulang, sesak napas, dada terasa tertekan, dan batuk khususnya pada malam atau dini hari. Gejala ini berhubungan dengan obstruksi saluran napas yang luas dan bervariasi dengan sifat sebagian reversibel baik secara spontan maupun dengan pengobatan (GINA, 2011).

Patofisiologis dari asma sendiri berhubungan dengan hipereaktivitas jalan napas terhadap berbagai rangsangan. Terdapat dua jalur hipereaktivitas yaitu jalur imunologis yang terutama didominasi oleh IgE, yaitu ketika allergen masuk ke dalam tubuh, alergen akan dimunculkan oleh APC (Antigen Presenting Cells), kemudian alergen akan dikenali oleh sel Th (T Helper) terutama $\mathrm{Th}_{2}$. Sel Th ini mengaktivasi interleukin atau sitokin agar sel-sel plasma membentuk IgE dan sel-sel radang lain untuk mengeluarkan mediator inflamasi seperti histamin, prostaglandin (PG), leukotrien (LT), platelet activating factor (PAF), bradikinin, tromboksin (TX), dan lainlain. Sel-sel ini bekerja dengan 
mempengaruhi organ sasaran yang dapat menginduksi kontraksi otot polos saluran pernapasan sehingga menyebabkan peningkatan permeabilitas dinding vaskular, edema saluran napas, infiltrasi sel-sel radang, hipersekresi mukus, keluarnya plasma protein melalui mikrovaskuler bronkus dan fibrosis sub epitel sehingga menimbulkan hipereaktivitas saluran napas. Faktor lain juga dapat mengakibatkan pelepasan mediator adalah latihan fisik, suhu udara, obatobatan, dan stress (Asthma Guideline, 2007).

Sementara pada jalur yang kedua yaitu jalur saraf otonom, terjadi reflek bronkus karena adanya peregangan pada saraf vagus, sedangkan pelepasan mediator inflamasi oleh sel mast dan makrofag akan membuat epitel jalan napas lebih permeabel dan memudahkan alergen masuk ke dalam submukosa, sehingga meningkatkan reaksi yang terjadi. (Bratawidjaja et al., 2006).

Orang yang menderita asma tidak memiliki kemampuan dasar untuk mendapatkan angka normal dari aliran udara ketika melakukan eskpiras. Ketidakmampuan ini dapat dilihat dari rendahnya volume udara yang dihasilkan saat melakukan pernapasan ekspirasi paksa pada detik pertama $\mathrm{FEV}_{1}$. tidak terjadi aerasi di paru dan hilangnya penyesuaian normal antara ventilasi dan aliran darah paru, hal ini dikarenakan banyaknya saluran udara yang menyempit tidak dapat dialiri dan dikosongkan secara tepat, (Supari, 2008).

Berdasarkan klasifikasi menurut gejala klinis, asma dibagi menjadi 4 derajat PDPI, 2012, yaitu, tahapan intermiten. Tahap ini gejala timbul setiap bulan dan kurang dari satu kali per minggu. Tanpa gejala di luar serangan dan serangan berlangsung singkat. Penilaian faal paru yaitu VEP $1 \geq 80 \%$ nilai prediksi, APE $\geq$ $80 \%$ nilai terbaik dan Variabiliti APE < $20 \%$. Selanjutnya, tahapan persisten ringan, gejala timbul setiap minggu dan lebih dari satu kali per minggu. Serangan dapat mengganggu aktifitas dan tidur. Penilaian faal paru yaitu VEP1 $\geq 80 \%$ nilai prediksi, APE $\geq 80 \%$ nilai terbaik dan Variabiliti APE 20$30 \%$. Pada tahapan persisten sedang, gejala timbul setiap hari, membutuhkan bronkodilator, dan mengganggu aktifitas serta tidur. Penilaian faal paru yaitu VEP1 60-80\% nilai prediksi, APE $60-80 \%$ nilai terbaik, dan Variabiliti APE > 30\%. Tahapan persisten berat yaitu gejala timbul terus menerus, sering kambuh, dan aktifitas fisik menjadi terbatas. Penilaian faal paru yaitu VEP1 $\leq 60 \%$ nilai prediksi APE, $\leq$ $60 \%$ nilai terbaik, dan Variabiliti APE > $30 \%$ (PDPI, 2012).

Penemuan tanda pada pemeriksaan fisik pasien asma, tergantung dari klasifikasi berdasarkan gejala klinis yang muncul. Pada pemeriksaan fisik pasien asma, terdapat perubahan anatomis bentuk thoraks, otot tambahan di leher sewaktu bernapas, napas menjadi cepat, sianosis, ekspirasi memanjang, serta pada pemeriksaan auskultasi terdapat suara mengi. Pemeriksaan spirometri adalah cara yang paling cepat dan sederhana untuk menegakkan diagnosis asma, hal ini dengan melihat respon pengobatan dengan menggunakan bronkodilator. Jika pemeriksaan spirometri normal, maka dapat dilakukan uji provokasi bronkus untuk menunjukkan adanya hipereaktivitas bronkus, uji ini menggunakan histamin, metakolin, larutan garam hipertonik, dan aqua destilata. Hasil bermakna bila didapat 
penurunan $\mathrm{VEP}_{1}$ sebesar $20 \%$ atau lebih Sundaru, Heru, (Sukamto, 2006)

Cermai atau ceremai (Phyllantus acidus) termasuk ke dalam keluarga Euphorbiaceae. Pohon cermai dapat tumbuh hingga 10 meter, daunnya majemuk menyirip, berbentuk lonjong dan duduk tersebar berseling, memiliki panjang 5-6 $\mathrm{cm}$ dan lebar 2-3 cm, ujung meruncing dengan tepian rata dan berwarna hijau muda. Bunga cermai berbentuk bulat, kelopaknya berbentuk bintang dengan permukaan halus, mahkota berwarna merah muda. Karakteristik buah cermai sendiri berbentuk bulat dengan permukaan berlekuk berwarna hijau dan kuning keputih-putihan, biji di dalamnya berbentuk bulat pipih berwarna coklat. Akar pohon merupakan akar tunggang (Hutapea, 1994)

Cermai adalah spesies tropis dan subtropis yang berasal dari Madagaskar dan didistribusikan ke Karibia pada 1793 ketika William Bligh membawa tanaman dari Timor ke Jamaika. Sekarang ditemukan di wilayah Karibia, Amerika Tengah dan Selatan, dan di seluruh Asia (Jules dan Paull, 2008).

Di Indonesia, kulit kayu dicampur dan dipanaskan dengan minyak kelapa, kemudian dioleskan pada kulit untuk menghilangkan rasa gatal (Lim, 2012). Di Filipina, rebusan kulit kayu digunakan untuk mengobati radang selaput lendir hidung (Tropical Plants Database, 2014). Daun ceremai berkhasiat untuk obat mual dan sariawan sementara akarnya untuk asma. Hutapea, 1994. Infus akar diambil dalam dosis kecil untuk mengurangi asma di Jawa (Orwa et al., 2009). Di Filipina, rebusan daun diterapkan pada urticaria (Tropical Plant Database, 2014). Infus daun digunakan sebagai bantuan diet untuk orang-orang yang berdiet dan ingin tetap langsing (Tropical Plant Database, 2014).

Buah cermai mengandung 91,1\% kadar air, sejumlah karbohidrat dan protein (Rahman dan Mosihuzzaman, 1991). Ekstrak buah mengandung asam askorbat $36,7 \mathrm{mg} / 10 \mathrm{~g}$ (Mahapatra et al. 2012). Terdapat mineral unsur makro (kalsium, magnesium, kalium dan fosfor) dan unsur mikro (besi, tembaga, seng dan mangan) (Shajib et al. 2013). Cermai terdiri dari terpenoid (diterpenoid, seskuiterpenoid, dan triterpenoid), nukleosida alami berupa adenosin, senyawa flavonoid dan fenolik. Sebagian besar senyawa yang diisolasi dari Cermai adalah terpenoid yang telah diisolasi dan diidentifikasi terutama dari kulit kayu dan akar cermai (Zheng et al., 2018). Penelitian fitokimia juga menyebabkan isolasi 14 flavonoid, glikosida Flavonol diisolasi dari daun, dan flavonoid yang mengandung asam sulfonat diisolasi dari akar cermai (Sousa, 2013).

Cermai telah digunakan untuk pengobatan beberapa penyakit termasuk gangguan yang berhubungan dengan inflamasi seperti ruam kulit, kulit psoriasis, radang selaput lendir hidung dan gangguan pernapasan seperti asma (Orwa et al., 2009). Asam askorbat yang dikandung cermai berperan sebagai antiasma, antihistamin dan antiinflamasi, niacin berperan sebagai antihistamin, sementara beta-carotene mempunyai kemampuan sebagai antiasma (Duke, 2007).

Meskipun mekanisme molekuler dari potensi terapeutik belum sepenuhnya dijelaskan. Secara umum diterima bahwa makrofag yang berhubungan dengan jaringan memainkan peran penting dalam hilangnya fungsi organ 
dengan melepaskan molekul toksik dan inflamasi seperti NO, ROS, PGE2, enzim hidrolitik, dan sitokin proinflamasi seperti IL-1 dan TNF- $\alpha$ (Byeon et al., 2012). Berbeda dengan mekanisme pertahanan normal dan menguntungkan, kejadian inflamasi yang dimediasi makrofag yang berkelanjutan dapat menyebabkan berbagai penyakit inflamasi di hati, paru-paru, perut, usus besar, dan sendi (Lyman et al., 2014). Kombinasi quercetin dan kaempferol dalam ekstrak ini berkontribusi, setidaknya sebagian, pada aksi anti-inflamasi PaME. Oleh karena itu, kami menyimpulkan bahwa peran etnofarmakologis yang dilaporkan sebelumnya dari tanaman ini dimediasi oleh penghambatan respon inflamasi makrofag yang diinduksi Pa-ME (Sousa et al., 2007). Dapat disimpulkan bahwa Quercetin dan kaempferol, dua komponen anti-inflamasi aktif dalam Pa-ME, mengurangi peradangan baik in vitro dan in vivo (Hossen, 2015).

Ekstrak tanaman obat tradisional Phyllanthus acidus (mayoritas) telah terbukti diperkaya dengan adenosin. Selain adenosin, cermai juga mengandung komponen lain yang mungkin mempengaruhi transpor elektrolit di saluran udara, seperti kaempferol flavonoid dan asam 2,3dihydroxybenzoic (DHBA). Ekstrak dari cermai mengaktifkan sekresi elektrolit dalam jaringan epitel melalui utusan kedua intraseluler dan secara langsung meningkatkan ekspresi membran dan aktivitas saluran ion ( $\mathrm{Li}$ dan Wang, 2004).

Selain itu, kalsium yang ada pada cermai dapat menghambat influx $\mathrm{Ca} 2+$ (Burgos et al., 2000). Hal ini dapat mencegah terjadinya degranulasi sel mast sehingga sekresi amin vasoaktif yang berperan dalam proses inflamasi pada peristiwa asma alergi akan berkurang. Histamin memainkan peran yang sangat penting pada patogenesis asma atopi melalui pengaturan diferensiasi limfosit sel CD4+ Th (Janeway et al., 2005).

\section{SIMPULAN}

Cermai dapat bermanfaat pada penyakit asma dikarenakan cermai memiliki kandungan anti inflamasi aktif yang mencegah respon alergi.

\section{DAFTAR PUSTAKA}

Abbas, A.K. dan Lichtman, A.H. (2003). Cellular and Molecular Immunology. Elsevier Science, USA, pp : 264, 443 - 8

Asthma Guideline. (2007). Definition, pathophysiology and pathogenesis of asthma, and natural history of asthma [homepage on internet]. Available from :http://www.nhlbi.nih.gov/guideli nes/asthma/03_sec_sec2_def.pdf.

Baratawidjaja KG, Soebaryo RW, Kartasasmita CB, Suprihati, Sundaru H, Siregar sp, et al. (2006). Allergy and asthma, The scenario in Indonesia. In Shaikh WA. Editor. Principles and practice of tropical allergy and asthma. Mumbai: Vikash Medical Publishers;.707-36

Burgos, R.A., Imilan, M., Sanchez, N.S., Hancke, J.L. (2000). Andrographis paniculata (Nees) selectively blocks voltageoperated calcium channels in rat vas deferens.J Ethnopharmacol. 71(1-2):115-121

Christophe W. (2006). Ethnopharmacology of medicinal plants: Asia and the pacific. New Jersey: Humana Press; 
Duke, J.A. (2007). List of Chemicals of Phyllanthus acidus (L.) Skeels. In: Phyto-chemical and Ethnobotanical Databases. http://www.natrindex.com/duke_p $\underline{\text { lant-G.html }}$

Guntur, H. (2004). Phyllanthi Niruri dan Penggunaannya pada Sistem Imun. Simposium Peralmuni Cab. Surakarta 15 Agustus 2004.

Goodman \& Gilman. (2012). Dasar Farmakologi Terapi, Edisi 10, Editor Joel. G. Hardman \& Lee E. Limbird, Konsultan Editor Alfred Goodman Gilman, Diterjemahkan oleh Tim Alih Bahasa Sekolah Farmasi ITB, Penerbit Buku Kedokteran EGC, Jakarta

Global strategy for asthma management and prevention. Global initiative for asthma (GINA). (2011). Downloaded from www.ginasthma.org

Hossen, M. J., S.H. Jeon, S. C. Kim, J. H. Kim, D. Jeong, N.Y. Sung, S. Yang, K. S. Baek, D. H. Yoon, W. O. Song, K. D. Yoon, S.H. Cho, S. Lee and J.Y. (2015). In vivo and in vivo anti-inflammatory activity of Phyllanthus acidus methanolic extract. J. Ethnopharmacol.

Janeway, C.A., Travers, P., Walport, M., Shlomchik, M., Shlomchik, M.J. (2005). Immunobiology. Edisi VI. Garland Science Publishing, USA.

Li, H. and Wang, Q. (2004). Evaluation of free hydroxyl radical scavenging activities of some Chinese herbs by capillary zone electrophoresis with amperometric detection. Anal Bioanal Chem 378:1801-1805.
Mahapatra, A.K., Mishra, S., Basak, U.C., Panda, P.C. (2012). Nutrient analysis of some selected wild edible fruits of deciduous forests of India: an explorative study towards non-conventional bionutrition. Adv. J. Food Sc. Tech. $4,15-21$.

PDPI (Perhimpunan Dokter Paru Indonesia). (2004). Asma dan Pedoman Pentalaksanaan di Indonesia. Jakarta: Balai penerbit FKUI.

Shajib, M.T.I., Kawser, M., Miah, M.N., Begum, P., Bhattacharjee, L., Hassain, A., Fomsgaard, I.S., Islam, S.N., (2013). Nutritional composition of minor indigenous fruits: Cheapest nutritional source for the rural people of Bangladesh. Food Chem. 140, 466-470.

Sousa, M., Ousingsawat, J., Seitz, R., Puntheeranurak, S., Regalado, A., Schmidt, A., Grego, T., Jansakul, C., Amaral, M.D., Schreiber, R., Karl, K.K., (2007). An extract from the medicinal plant Phyllanthus acidus and its isolated compounds induce airway secretion: a potential treatment for cystric fibrosis. Mol. Pharmacol. 7, 366-376.

Subijanto dan Diding. (2007). Aerosolized Ovalbumin Exposure Facilitates Changes Serum Ig E Level in Mouse. Dipresentasikan pada Simposium Reuni Akbar Fakultas Kedokteran: 18 Maret 2007, Surakarta

Sundaru, Heru, Sukamto. (2006). Asma Bronkial dalam Sudoyo, Aru W, B. Setiyohadi, I. Alwi, M. Simadhibrata, S. Setiati, editor. Ilmu Penyakit Dalam Jilid 1. 
Jakarta: Departemen Ilmu Penyakit Dalam FK UI. pp. 24550

Supari, SF. (2008). Pedoman Pengendalian Penyakit Asma. Jakarta: DEPKES.

Sahab U, Mamun A., Hossain S., Ashaduzzaman, M., Noor A.

A., Hossain S. (2016). Neuroprotective of Phyllanthus Effect acidus L. on
Learning and Memory Impairment in ScopolamineInduced Animal Model of Dementia and Oxidative Stress: Natural Wonder for Regulating the Development and Progression of Alzheimer's Disease. AAD Vol 5 No. 2

Tropical Plants Database, Ken Fern, (2014). tropical.theferns.info. 